\title{
Retraction Note: Gene expression profiling analysis of hepatocellular carcinoma
}

Deyong Kong ${ }^{1 \dagger}$, Heming Chen ${ }^{2+}$, Weiqun Chen ${ }^{3,4+}$, Shuiyi Liu ${ }^{4}$, Hui Wang ${ }^{1}$, Tangwei Wu' ${ }^{1}$, Hongda Lu ${ }^{4,5}$, Qingzhi Kong ${ }^{3,4,5}$, Xiaodong Huang ${ }^{3,4^{*}}$ and Zhongxin Lu $\mathrm{u}^{1,3,4^{*}}$

\section{Retraction}

The Publisher and Editor regretfully retract this article [1] because the peer-review process was inappropriately influenced and compromised. As a result, the scientific integrity of the article cannot be guaranteed. A systematic and detailed investigation suggests that a third party was involved in supplying fabricated details of potential peer reviewers for a large number of manuscripts submitted to different journals. In accordance with recommendations from COPE we have retracted all affected published articles, including this one. It was not possible to determine beyond doubt that the authors of this particular article were aware of any third party attempts to manipulate peer review of their manuscript.

\section{Author details}

${ }^{1}$ Department of Medical Laboratory, Central Hospital of Wuhan, Wuhan 430014, China. ${ }^{2}$ Department of Cardiovascular and Thoracic Surgery, Second Xiangya Hospital, Central South University, Changsha 410078, China. ${ }^{3}$ Department of Central Laboratory, Central Hospital of Wuhan, Wuhan 430014, China. ${ }^{4}$ Cancer Research Institute of Wuhan, Wuhan 430014, China. ${ }^{5}$ Department of Oncology, Central Hospital of Wuhan, Wuhan 430014, China.

Received: 22 January 2015 Accepted: 2 March 2015

Published online: 26 March 2015

\section{References}

1. Kong D, Chen H, Chen W, Liu S, Wang H, Wu T, et al. Gene Expression profiling analysis of hepatocellular carcinoma. Eur J Med Res. 2013;18:44.

\footnotetext{
* Correspondence: huangxiaodong88@163.com; Izx71@yahoo.com ${ }^{\dagger}$ Equal contributors

${ }^{3}$ Department of Central Laboratory, Central Hospital of Wuhan, Wuhan 430014, China

'Department of Medical Laboratory, Central Hospital of Wuhan, Wuhan 430014, China

Full list of author information is available at the end of the article
}

\section{Submit your next manuscript to BioMed Central and take full advantage of:}

- Convenient online submission

- Thorough peer review

- No space constraints or color figure charges

- Immediate publication on acceptance

- Inclusion in PubMed, CAS, Scopus and Google Scholar

- Research which is freely available for redistribution

\section{Biomed Central}

(c) 2015 Kong et al.; licensee BioMed Central. This is an Open Access article distributed under the terms of the Creative Commons Attribution License (http://creativecommons.org/licenses/by/4.0), which permits unrestricted use, distribution, and reproduction in any medium, provided the original work is properly credited. The Creative Commons Public Domain Dedication waiver (http://creativecommons.org/publicdomain/zero/1.0/) applies to the data made available in this article, unless otherwise stated. 